\title{
Third Party Funds and Non-Performing Financing for Mudharabah Financing in Indonesia's Sharia Banking
}

\author{
Nur'aeni $^{1 *}$, Setiawan $^{2}$ \\ ${ }^{1}$ Departement of Islamic Banking, Univeristas Ma'soem, Bandung, Indonesia \\ ${ }^{2}$ Departement of Accounting, Politeknik Negeri Bandung, Bandung, Indonesia \\ *Corresponding author e-mail address: nuraeni.mesy@gmail.com
}

\begin{abstract}
Mudharabah financing is the core of sharia banks and based on the profit sharing. In sharia principles, it is considered as a characteristic of sharia banks. This study aims to find out the influence of third party funds and nonperforming financing on mudharabah financing in Indonesia's Sharia Banking. This research employed quantitative research methods using associative approach with the type of secondary data. The data analysis used Partial Least Square (PLS) with the Structural Equation Modeling (SEM) approach, while the application used was WarpPLS. The results revealed that TPF has a significant effect on Mudharabah Financing, while NPF has not. This is indicated by a coefficient value of 0.63 and ap-value of 0.000 for the effect of TPF on Mudharabah Financing. Meanwhile, the influence of NPF on Mudharabah Financing has a coefficient of 0.13 and a p-value of 0.16.
\end{abstract}

Keywords: third party funds; non-performing financing; mudharabah financing.

\section{Introduction}

Sharia finance institution is a financial institution whose principles is based on sharia principles. This is different from conventional banking which only prioritizes the principle of profit. The development of Islamic banking has developed rapidly compared to conventional banking (Suhartanto et al., 2018; Suhartanto et al., 2019). Many customers have used sharia banking products but some are still using conventional banking. Generally, the products offered Islamic banking is divided into three parts, namely, product distribution of funds (financing), products fund (funding), and the product of service (service) (Firmansyah, 2016). Sharia banking products has a purpose to prioritize the community's welfare and help their standard of living. The financing product offered to customers is in the form of mudharabah financing, musyarakah and murabahah (Pratiwi, 2018).

Nowadays, Indonesia has 14 Sharia Commercial Banks and 20 Sharia Business Units (OJK, 2019). Sharia banking is an alternative to choose a bank that is free from usury in its operational activities. One of the products for channeling funds in sharia banks is mudharabah financing. In order the distribution of funds runs smoothly, of course, it must be supported by the collection of funds, one of which is from Third Party Funds (TPF) (Kustina, 2019). TPF collected from the wider community is the most important source for the operation of a bank (Dafe and Williams, 2020). If the funds are not good, it will affect the financing. These third party funds are obtained by sharia banks from wadiah demand deposits, wadiah savings, mudharabah and mudharabah deposits (Sholikhah et al., 2017). The amount of NPF allowed in 
Bank Indonesia is 5\%, if exceeding 5\% will affect the rating of the bank health concerned that will reduce the value of score obtained (Kinanti and Purwohandoko, 2017).

Besides TPF, Non-Performing Financing (NPF) also greatly supports the financial stability of allocation. NPF is a financial ratio used to assess bank performing in managing productive assets, especially in managing non- performing financing provided by banks (Utomo et al., 2016). NPF is a frightening aspect for banks. Moreover, experience has shown that one of the causes of the economic crisis is a poor banking performance (Hijriyani and Setiawan, 2017). The high NPF, especially bad debts, contributed greatly to the poor performance of banks at that time. NPF is indeed an indicator of a bank's health (Ghoniyah and Hartono, 2020). If the NPF in a bank is higher, the level of risk that will be obtained will also be higher (Rofi'ah and A'yun, 2019). NPF height is strongly influenced by the bank's ability to execute with good credit granting process and in terms of credit management, including monitoring measures after the loans were disbursed and control measures when there are indications of irregularities or indications of defaulted loans. The higher this ratio the more the worse the quality of bank loans that caused the greater number of problem loans, the possibility of a bank in the greater problematic conditions. Loans in this case are loans granted to third parties excluding loans to other banks. Non-performing loans are loans classified as substandard, doubtful and loss (Husaeni, 2016). Financial management in banks is certainly an indicator of success in managing the banking business. Sharia banks that can manage their financial well can generate NPF at a low level by contributing a high profits.

The development of Third Party Funds, Non-Performing Financing, and Mudharabah Financing for the period of 2015 to 2019 as seen from the Sharia Banking Statistic Report experienced dynamic movement. TPF values fluctuated but tended to increase significantly, while non-performing financing fluctuated but tended to decrease. Mudaraba financing has fluctuated but tends to be constant in a certain range. An increase in the value of TPF should have an impact on increasing the value of mudharabah financing, but in the 2015 and 2019 period, there was no visible increase in TPF which encouraged an increase in the value of mudharabah financing. This is not in accordance with the statement of Kasmir saying that TPF is the most important source of funds for bank funding activities and is a measure of a bank success if the bank is able to finance its operations from this source of funds (De Jonghe, 2010). Meanwhile, the NPF value from 2015 to 2019 continually tends to decrease. A decrease in the value of the NPF should have an impact on the increase in the value of mudharabah financing, however, the value of mudharabah financing does not increase significantly. This is not in accordance with the findings of Reni and Ahmad (2016), that the higher the NPF value, the lower the bank's financing will be, conversely if the NPF is lower, the greater the mudharabah financing will be obtained.

Reni and Ahmad (2016) presents an analysis of TPF and risks on mudharabah and musyarakah financing at Sharia Commercial Banks in Indonesia which results that partially and simultaneously TPF and risk have a positive and significant effect on mudharabah and musyarakah financing. In addition, Anwar and Miqdad studied the effect of Third Party Funds (TPF), Capital Adequacy Ratio (CAR), and Return On Assets (ROA) on mudharabah financing at Islamic Commercial Banks from 2008 to 2012. The results showed that partially and simultaneously TPF, CAR and ROA have a positive and significant effect on mudharabah financing (Anwar and Miqdad, 2017). Research from Ali and Miftahurrohman (2015) entitled analysis of the effect of DPK, NPF and credit interest rates on profit-sharing based financing (mudharabah) in Indonesian Islamic banking. The results showed that partially TPF has a positive and significant effect on mudharabah financing, partially NPF does not have a positive and significant effect on mudharabah financing and simultaneously TPF, NPF and credit interest rates have a positive and significant effect on mudharabah financing. Previous research was conducted through regression analysis and using annual data from Sharia banking.

This study tries investigate deeply the effect of TPF and NPF on Mudharabah Financing by using a data analysis approach that is different from previous studies. This study emlpoyes the Partial Least 
Square (PLS) - Structural Equation Modeling (SEM) approach using the help of the WarpPLS application.

\section{Methodology}

This research employed quantitative research methods using an associative approach. The data used are secondary data obtained from sharia banking statistical reports published by the Financial Services Authority. The report is in the form of monthly data which is a combination of all Sharia Commercial Banks and Sharia Business Units for the period of 2015 to 2019. This research used documentation techniques in collecting the data. The data analysis used Partial Least Square (PLS) with the Structural Equation Modeling (SEM) approach, while the application used was WarpPLS.

\section{Results and Discussion}

\subsection{Descriptive Statistics}

Before coming to the data analysis, descriptive statistical analysis was conducted in advance. Descriptive statistical analysis was performed to provide information about the mean score, standard deviation, minimum, maximum and median of the processed data. Descriptive statistical analysis is presented in Table 1.

Table 1. Descriptive Statistics

\begin{tabular}{lrrr}
\hline & \multicolumn{1}{c}{ TPF } & NPF & Mudharabah \\
\hline Mean & 300346.67 & 0.04093 & 15003.89 \\
Standard Error & 8316.94 & 0.0009069 & 123.09351 \\
Median & 304770.31 & 0.043 & 14769.97 \\
Standard Deviation & 64422.75 & 0.0070252 & 953.47823 \\
Sample Variance & 4150291042 & $4.93537 \mathrm{E}-05$ & 909120.743 \\
Kurtosis & -1.375844098 & -1.218972612 & -0.64100612 \\
Skewness & 0.047062335 & -0.155492578 & 0.48498201 \\
Range & 206260.50 & 0.026891125 & 3680.36760 \\
Minimum & 210297 & 0.0285 & 13409 \\
Maximum & 416557 & 0.0554 & 17090 \\
Sum & 18020800 & 2.456313326 & 900233.25 \\
Count & 60 & 60 & 60 \\
Confidence & 16642.16 & 0.001814806 & 246.30954 \\
Level(95.0\%) & & & \\
\hline
\end{tabular}

Based on THE descriptive statistical testing in table 1 above, it can be seen that the average TPF is $300,346.67$ billion, the smallest value of 210,297 was obtained in February 2015, and the largest value of 416,557 was obtained in December 2019. Average NPF is about 4.093 percent, the smallest value of 2.85 percent was obtained in December 2018, and the largest value of 5.54 percent was obtained in May 2016. The average mudarabah financing was 15.003 .89 billion, the smallest value of 13.409 was obtained in October 2019, and the largest value of 17.089 was obtained in December 2017

\subsection{Goodness of Fit Model Testing}

Goodness of Fit Model Testing is a feasibility test used to check and test the accuracy of the sample regression function tested in estimating the actual value. The Goodness of Fit Model test on the testing model for Third Party Funds and Non-Performing Financing on Mudharabah Financing is presented in the following Table 2 
Table 2. Goodness of Fit Model

\begin{tabular}{|c|c|c|c|}
\hline Index & Criteria & Value & Result \\
\hline Average Path Coefficient (APC) & $\mathrm{P}<0.05$ & $0.379, \mathrm{P}<0.001$ & Accepted \\
\hline Average R-Square (ARS) & $\mathrm{P}<0.05$ & $0.497, \mathrm{P}<0.001$ & Accepted \\
\hline Average Adj R-Square (AARS) & $\mathrm{P}<0.05$ & $0.479, \mathrm{P}<0.001$ & Accepted \\
\hline Average Block VIF (AVIF) & $\begin{array}{r}\text { Acceptable if } \leq 5, \text { ideally } \\
\leq 3.3\end{array}$ & 1.361 & Accepted \\
\hline $\begin{array}{l}\text { Average Full Collinearity VIF } \\
\text { (AFVIF) }\end{array}$ & $\begin{array}{r}\text { Acceptable if } \leq 5, \text { ideally } \\
\leq 3.3\end{array}$ & 5.053 & Rejected \\
\hline $\begin{array}{l}\text { Tenenhaus Goodness of Fit } \\
(\mathrm{GoF})\end{array}$ & $\begin{array}{r}\text { Small } \geq 0.1, \text { medium } \geq \\
0.25, \text { large } \geq 0.36\end{array}$ & 0.705 & Accepted, large \\
\hline $\begin{array}{l}\text { Sympson's Paradox Rasio } \\
\text { (SPR) }\end{array}$ & $\begin{array}{r}\text { Acceptable if } \geq 0.7, \\
\text { ideally }=1\end{array}$ & 1.000 & Accepted \\
\hline $\begin{array}{l}\text { R-Square Contribution Rasio } \\
\text { (RSCR) }\end{array}$ & $\begin{array}{r}\text { Acceptable if } \geq 0.9, \\
\text { ideally }=1\end{array}$ & 1.000 & Accepted \\
\hline $\begin{array}{l}\text { Statistical Suppression Rasio } \\
\text { (SSR) }\end{array}$ & Acceptable if $\geq 0.7$ & 1.000 & Accepted \\
\hline $\begin{array}{l}\text { Nonlinear bivariate causality } \\
\text { direction ratio (NLBCDR) }\end{array}$ & Acceptable if $\geq 0.7$ & 1.000 & Accepted \\
\hline
\end{tabular}

There is one measure of Goodness of Fit that does not meet the criteria to be used as the basis for further analysis. Given that the purpose of this study is to test hypotheses between variables, there are no specific provisions regarding the required GoF value. Although the table above shows that not all measures have a value above the cut-off value, it can be said that the model can be used to test the established hypothesis (Kock, 2017).

\subsection{Data Analysis}

The data analysis begins with a model-based theory creation. The theoretical model that has been described is then made into a path diagram. This path diagram shows the relationships between constructs which can be seen through the arrows. Straight arrows will show direct causal relationships between them. Meanwhile, curved lines between constructs with arrows at each end indicate the correlation between constructs.

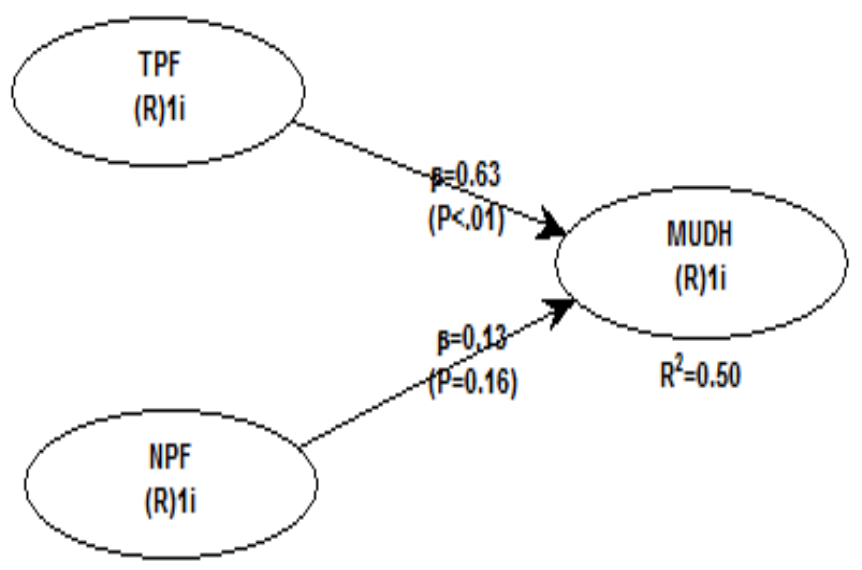

Figure 1. Structural Model 
The structural model shown in Figure 1 showed the results of testing the effect of TPF and NPF on mudharabah financing using WarpPLS assistance. In detail, the interpretation of the processing results can be seen in Table 3.

Table 3. Path Coefficient

\begin{tabular}{cccc}
\hline Path & Coefficient & P-Value & Result \\
\hline TPF $=>$ Mudharabah Financing & 0.63 & $<0.01$ & Significant \\
NPF $=>$ Mudharabah Financing & 0.13 & 0.16 & Not significant \\
\hline
\end{tabular}

It is known from the Table 3 that the effect of TPF on Mudharabah Financing is 0.63 and the p-value is 0.000 . At the 1\% significance level, the effect of TPF on Mudharabah Financing is significant because the p-value is $<0.01$, so it can be interpreted that TPF has a significant positive effect on Mudharabah Financing. Meanwhile, the influence of NPF on Mudharabah Financing is 0.13 and the p-value is 0.16 . At the $1 \%$ or $5 \%$ significance level, the influence of NPF on Mudharabah Financing is not significant because the p-value is $>0.05$, so it can be interpreted that NPF has no effect on Mudharabah Financing.

TPF is a very strong indicator in describing the development of a bank, even a bank can run its operations when it is supported by the large of its TPF (Yulianto and Solikhah, 2016). Based on Figure 1 above, sharia banking deposits show a significant increasing trend, which means that sharia banks are experiencing a fairly good development. Thus, sharia banks are able to distribute a large mudharabah financing if the deposits that have been collected are also large. Sharia banks have a more flexible opportunity in arranging financial allocations or for other purposes. The results of this study are in line with previous studies such as (Anwar and Miqdad, 2017, Machmud et al., 2018; Yulianto and Solikhah, 2016) proving that TPF has a positive effect on Mudharabah Financing.

The NPF of sharia banking tends to decrease from year to year, this shows that the financial management of sharia bank is getting better. So that NPF does not interfere with the distribution of financing, especially mudharabah financing. Sharia banks have the courage to continue distributing their financing without being pressured by the NPF value. So that the results of this study confirm that there is no influence between NPF and mudharabah financing.

\section{Conclussion}

This study succeeded in confirming that TPF has a significant effect on Mudharabah Financing. Meanwhile, NPF does not have a significant effect on Mudharabah Financing. The results of this study are expected to encourage managers in sharia banking to formulate strategies in order to continue to increase the amount of TPF which is considered as the main strength of banks, both conventional and sharia. Especially for sharia banks, it is hoped that the managers can allocate large amounts of financing for mudharabah products because mudharabah financing is identified as a characteristic of sharia banks as a profit-sharing based financial institution.

\section{References}

Ali, H, \& Miftahurrohman, (2015), Analisis Pengaruh Dana Pihak Ketiga, Tingkat Bagi Hasil, Non Performing Financing Dan Profitabilitas Terhadap Volume Pembiayaan Berbasis Bagi Hasil Pada Perbankan Syariah Di Indonesia, J. Tauhidinomics, 1(2), 151-166.

Anwar, C., \& Miqdad, M. (2017). Pengaruh Dana Pihak Ketiga (DPK), Capital Adequacy Ratio (CAR), Return On Asset (ROA) Terahadap Pembiayaan Mudharabah Pada Bank Umum Syariah Tahun 2008-2012. Owner (Riset dan Jurnal Akuntansi), 1(1), 1-12. 
Dafe, F., \& Williams, Z. (2020). Banking on courts: financialization and the rise of third-party funding in investment arbitration. Review of International Political Economy, 1-23.

De Jonghe, O. (2010). Back to the basics in banking? A micro-analysis of banking system stability. Journal of financial intermediation, 19(3), 387-417.

Firmansyah, M. (2016). Implementation of Contract Hybrid Concept in Multi Services Products (Aplication of the Warranty Bank Products/Kafalah in Syariah Banks). International Journal of Nusantara Islam, 4(2), 85-96.

Ghoniyah, N., \& Hartono, S. (2020). How Islamic and conventional bank in Indonesia contributing sustainable development goals achievement. Cogent Economics \& Finance, 8(1), 1856458.

Hijriyani, N. Z., \& Setiawan, S. (2017). Analisis Profitabilitas Perbankan Syariah di Indonesia sebagai Dampak Dari Efisiensi Operasional. Jurnal Kajian Akuntansi, 1(2).

Husaeni, U. A. (2016). The Variables that Affect Murābaha Financing in Islamic Commercial Banks. International Journal of Nusantara Islam, 4(2), 1-16.

Kinanti, R. A., \& Purwohandoko, P. (2017). Influence of third-party funds, Car, NPF and FDR towards the return On assets of Islamic banks in Indonesia. JEMA: Jurnal Ilmiah Bidang Akuntansi dan Manajemen, 14(2), 135143.

Kock, N. (2017). WarpPLS user manual: Version 6.0. ScriptWarp Systems: Laredo, TX, USA.

Kustina, K. T., Dewi, G. A. A. O., Prena, G. D., \& Suryasa, W. (2019). Branchless banking, third-party funds, and profitability evidence reference to banking sector in indonesia. Jour of Adv Research in Dynamical \& Control Systems,(11), 2, 290-299.

Machmud, A., Herlinawati, E., \& Supriyadi, D. (2018). The Determinants of Sharia Banking Finance Performance in Indonesia. Advanced Science Letters, 24(7), 4882-4885.

OJK, “Statistik Perbankan Syariah,” Jakarta: Otoritas Jasa Keuangan, 2019.

Pratiwi, F. N. (2018). Pengaruh FDR, DPK, ROA Terhadap Pembiayaan Di Bank Syariah (Studi Kasus Pada Bank Syariah Mandiri). Jurnal Education and Economics, 1(3), 037-048.

Reni, A., \& Ahmad, N. H. (2016). Application of theory reasoned action in intention to use Islamic banking in Indonesia. Al-Iqtishad: Jurnal Ilmu Ekonomi Syariah, 8(1), 137-148.

Rofi'ah, K., \& A'yun, A. A. (2019). Faktor-Faktor Non-Performing Financing (NPF) di Bank Umum Syariah Indonesia. Jurnal Ekonomi, 24(3), 452-467.

Sholikhah, Z., Pramuka, B. A., \& Adawiyah, W. R. (2017). Determinant of the equity based financing volume: A case of Islamic banks in Indonesia. Research Journal of Finance and Accounting, 8(1), 30-39.

Suhartanto, D., Farhani, N. H., \& Muflih, M. (2018). Loyalty Intention towards Islamic Bank: The Role of Religiosity, Image, and Trust. International Journal of Economics \& Management, 12(1), 137-151.

Suhartanto, D., Gan, C., Sarah, I. S., \& Setiawan, S. (2019). Loyalty towards Islamic banking: service quality, emotional or religious driven?. Journal of Islamic Marketing, 11(1), 66-80.

Utomo, A. S., Maharani, N. K., \& Octavio, D. Q. (2016). Financial Determinants of Qardhul Hasan Financing Growth: Evidence from Islamic Banks in Indonesia. Global Review of Islamic Economics and Business, 3(1), 038-045. 
Yulianto, A., \&Solikhah, B. (2016). The internal factors of Indonesian Sharia banking to predict the mudharabah deposits. Review of Integrative Business and Economics Research, 5(1), 210-224. 